\section{Irish Science Policy}

THE Irish Civil Service Commissioners have recently been advertising for scientists to take the post of secretary-general of the new National Science Council, set up at the end of 1967 . The science council itself sprang from recommendations made in a report called Science and Irish Economic Development, prepared by a survey team appointed by the Minister for Industry and Commerce in 1963 (Stationery Office, Dublin, $7 s .6 d$.). The survey team seems to have been at a loss to decide who should receive the report and put its recommendations into action, and therefore decided to make the formation of the National Science Council the principal recommendation of its report. The council is to be concerned with natural sciences, engineering, architecture, agricultural and veterinary sciences, and health and social sciences. This is a very wide-ranging brief, and the survey team was led to recommend it after examination of the systems which operate in Israel, Norway, Netherlands and Spain. The schemes which operate in larger countries, the report remarks tartly, are extremely complicated and often unsatisfactory. "They have evolved in such a piecemeal and ad hoc fashion as to be almost useless except as examples of what to avoid in a small country."

The task of the council will be to provide advice to the Irish Government through the Minister for Finance, to whom it will directly report. It seems that the council will not be dispensing funds of its own, but simply advising the Government on the best distribution of funds between the competing interests. In addition to the central council, which is to be chaired by Professor C. O. hEocha, professor of biochemistry at the University College of Galway, the National Science Council will be able to set up divisional councils devoted to particular fields of activity. These divisional councils would generally include representatives from all the interests involved, but the central council would not be a representative body.

Although the remit of the council is wide, the actual budget for science in Ireland is of course small. In 1963 the total spent on research and development was only $£ 3.83$ million, including a contribution of $£ 1 \cdot 2$ million from industry, which barely qualifies as true research expenditure. The survey team said that this figure was very low by comparison with countries such as Norway, which spent $£ 14 \cdot 6$ million in the same year, for a population only 25 per cent larger than that of Ireland. As befits an economy still based firmly on agriculture, very nearly half the research expenditure goes on agricultural research, and another 39 per cent is spent on industrial research. The agricultural research body, An Foras Taluntais, is the biggest spender. But as Ireland is now working hard to encourage industry by means of generous tax concessions, one of the first responsibilities of the science council may be to tell the Government that not enough is being spent. The new secretary-general, when he is appointed, may find that the immediate need is not to decide on priorities, but to drum up support.

\section{0,000 Ton-up Boys}

Where will the oil companies discharge their giant tankers? Memories of the Torrey Canyon are still far too fresh for anyone, and least of all an oil com- pany, to be surprised by the reaction which greeted Shell's announcement last week that it intends partially to unload its 200,000 ton tankers at sea, some five miles off the coast. The company did nothing to inspire confidence by saying that because the operations will take place outside the territorial limit, the company was not strictly obliged to ask anyone's permission. It was also tactless to say that if oil is spilt it would probably drift into the Atlantic rather than ashore. But Shell, of course, has found itself in a difficult position. It won hands down the scramble for 200,000 and 300,000 ton tankers among the big seven oil companies, who relish calling themselves the seven deadly sisters. (And after Torrey Canyon who can quarrel with that?) Of the seven 200,000 ton tankers now afloat, Shell owns four and has a fifth on charter. It plans to get as many as ten or eleven more into service in the next year, and by the mid1970 s expects to own a fleet of twenty-two and to have seven more on charter.

Being first in the field, Shell claims to have bought its tankers more cheaply than its competitors. When the orders were placed, the shipbuilders were looking for work, but as orders rolled in, prices went up. The only snag in Shell's plans is that the size of the ships is not yet matched by that of any of the ports now available in Britain for ships drawing 63 feet of water. So Shell has either to run the tankers 30,000 tons light and, drawing 54 feet, enter one of its European terminals at Rotterdam, Goteburg, Le Havre or Marseilles or partially unload at sea. The first option could cost up to $£ 150,000$ a run, so Shell has chosen the second. As plans stand, a 70,000 ton tanker will tie up to the 200,000 tonner moving at 3 knots up the English channel. The vessel will anchor and, it is said, with the maximum of precautions 30,000 tons of oil will be pumped into the smaller vessel so the big tanker can sail to a port on the mainland of Europe. Shell claims that the operation will not be attempted in bad weather - defined as a force 5 or stronger wind or in six feet or higher waves; simulations made last winter have apparently suggested that it is more economic to have a fully laden tanker occasionally at anchor for two or three days waiting for good weather than to run the ships 30,000 tons light. Although all this is only a temporary measure, Shell can certainly expect very close scrutiny of its operations.

But Shell's problems are after all about to become those of the whole industry. What do the other companies-Gulf, BP, Esso, Mobil, Texaco and California Oil-intend to do ? They all no doubt hope that by the time most of their ships are in service, the ports will be ready. Only Esso, which has one 190,000 and one 170,000 tonner in service, faces the problem now and these ships should be able to get into Milford Haven as it is. Esso's refinery at Fawley will be supplied either by smaller tankers or by the big ones after they have partially discharged at Milford Haven. Mobil, without facilities at Milford Haven, also intends to use a two port discharge system; ships will partially discharge at Le Havre or Rotterdam and then sail to Coryton on the Thames. Texaco with facilities at Milford Haven should have no problems when it receives its six 200,000 tonners that are on the stocks. California Oil, which has a refinery near Rotterdam, has only just started operations in Britain and has no fixed plans as yet. 